\title{
SUFFICIENT CONDITIONS FOR EXISTENCE OF SOLUTIONS OF NONLINEAR DIFFERENTIAL EQUATIONS WITH NONLOCAL BOUNDARY CONDITIONS
}

\section{KRISTEN KOBYLUS ABERNATHY}

Abstract. We provide easily verifiable sufficient conditions for the existence of solutions to nonlinear ordinary differential equations subject to nonlocal boundary conditions. These conditions are based on the solution space of the corresponding linear, homogeneous problem and on the size of the nonlinear perturbation. The results presented here are more general nonlinearities than those in [17] and [26].

Mathematics subject classification (2010): 34B10, 34B15.

Keywords and phrases: boundary value problems, Schauder fixed point theorem.

\section{REFERENCES}

[1] R.P. Agarwal, S. Djebali, T. Moussaoui, and O.G. Mustafa, On the asymptotic integration of nonlinear differential equations, Journal of Computational and Applied Mathematics, 2 (2007), 352-376, doi:10.1016/j.cam.2005.11.038.

[2] S. BANCROFT, J.K. HALE AND D. SWEET, Alternative problems for nonlinear functional equations, Journal of Differential Equations, 4 (1968), 40-56, doi:10.1016/0022-0396(68)90047-8.

[3] L. CESARI, Functional analysis and periodic solutions of nonlinear differential equations, Contributions to Differential Equations, 1 (1963), 149-187.

[4] L. CesARI, Functional analysis and Galerkin's method, Michigan Mathematical Journal, 11 (1964), 385-414, doi:10.1307/mmj/1028999194.

[5] S. Chow AND J.K. Hale, Methods of Bifurcation Theory, Springer, Berlin, 1982.

[6] D. Etheridge And J. RodríGuez, Periodic solutions of nonlinear discrete-time systems, Applicable Analysis, 62 (1996), 119-137, doi:10.1080/00036819608840473.

[7] D. ETHERIdge AND J. Rodríguez, Scalar discrete nonlinear two-point boundary value problems, Journal of Difference Equations and Applications, 4 (1998), 127-144, doi:10.1080/10236199808808133.

[8] M. HajJi, Multi-Point Special Boundary-Value Problems and Applications to Fluid Flow Through Porous Media, Proceedings of the International MultiConference of Engineers and Computer Scientists, 2, (2009).

[9] A. HalAnAY, Solutions periodiques et presque-periodiques des systemes d'equations aux differences finies, Arch Rational Mech. Anal., 12 (1963), 134-149, doi:10.1007/BF00281222.

[10] J.K. HALE, Applications of alternative problems, Lecture Notes, vol. 71-1, Brown University, Providence, RI, 1971.

[11] J.K. Hale, Ordinary Differential Equations, Robert E. Kreiger Publishing Company, Malabar, Florida, 1980.

[12] E.M. LANDesman AND A.C. LAZER, Nonlinear perturbations of linear elliptic boundary value problems at resonance, Journal of Mathematics and Mechanics, 19 (1970), 609-623.

[13] D.C. LEWIS, On the role of first integrals in the pertubation of periodic solutions, The Annals of Mathematics, Second Series, 63 (1956), 535-548.

[14] R. MA AND Y. YANG, Existence result for a singular nonlinear boundary value problem at resonance, Nonlinear Analysis: Theory, Methods, \& Applications, 68 (2008), 671-680, doi:10.1016/j.na.2006.11.030. 
[15] J. RoDRÍGUEZ, An alternative method for boundary value problems with large nonlinearities, Journal of Differential Equations, 43 (1982), 157-167, doi:10.1016/0022-0396(82)90088-2.

[16] J. RodRíGUEZ, Nonlinear differential equations under Stieltjes boundary conditions, Nonlinear Analysis, 7 (1983), 107-116, doi:10.1016/0362-546X(83)90109-8.

[17] J. RODRÍGUEZ, Nonlinear multipoint boundary value problems at resonance, International Journal of Pure and Applied Mathematics, 54 (2009), 215-226.

[18] J. RodríGUez, On resonant discrete boundary value problems, Applicable Analysis, 19, (1985), 265-274, doi:10.1080/00036818508839551.

[19] J. RoDRÍGUEZ, Galerkin's method for ordinary differential equations subject to generalized nonlinear boundary conditions, Journal of Differential Equations, 97 (1992), 112-126, doi:10.1016/00220396(92)90086-3.

[20] J. RodRíGueZ, Nonlinear discrete Sturm-Liouville problems, Journal of Mathematical Analysis and Applications, 308 (2005), 380-391, doi:10.1016/j.jmaa.2005.01.032.

[21] J. RodrígUEZ AND K. ABERNATHY, On the solvability of nonlinear boundary value problems, Differ. Equ. Appl., 2 (2010), 487-499.

[22] J. RodRíGUEZ AND K. ABERNATHY, Nonlocal boundary value problems for discrete systems, Journal of Mathematical Analysis and Applications, 385 (2012), 49-59, doi:10.1016/j.jmaa.2011.06.028.

[23] J. RodRíGUEZ AND D. SWEET, Projection methods for nonlinear boundary value problems, Journal of Differential Equations, 58 (1985), 282-293, doi:10.1016/0022-0396(85)90017-8.

[24] J. RODRÍGUEZ AND P. TAYLOR, Weakly nonlinear discrete multipoint boundary value problems, Journal of Mathematical Analysis and Applications, 329 (2007), 77-91, doi:10.1016/j.jmaa.2006.06.024.

[25] J. RODRÍGUEZ AND P. TAYLOR, Scalar discrete nonlinear multipoint boundary value problems, Journal of Mathematical Analysis and Applications, 330 (2007), 876-890, doi:10.1016/j.jmaa.2006.08.008.

[26] J. RODRÍGUEZ AND P. TAYLOR, Multipoint boundary value problems for nonlinear ordinary differential equations, Nonlinear Analysis, 68 (2008), 3465-3474, doi:10.1016/j.na.2007.03.038.

[27] N. Rouche and J. Mawhin, Ordinary Differential Equations, Pitman, London, 1980.

[28] W. SPEALMAN AND D. SWEET, The alternative method for solutions in the kernel of a bounded linear functional, Journal of Differential Equations, 37 (1980), 297-302, doi:10.1016/0022-0396(80)90100$\mathrm{X}$. 